\title{
IAMJ
}

INTERNATIONAL

AYURVEDIC

MEDICAL JOURNAL

\section{A REVIEW ON CLINICAL IMPORTANCE OF PANCHAKARMA IN VRANA SHASTI UPAKRAMAS}

\section{$\underline{\text { Dipanjan Jana }}^{1}, \underline{\text { Raghunath Das }}^{2}, \underline{\text { Durbadal Majumdar }}^{4}, \underline{\text { Suman Kundu }}^{4}$}

${ }^{1}$ Associate Professor Depart of Panchakarma, Raghunath Ayurved Mahavidyalaya and Hospital, Contai, W.B., India

${ }^{2}$ RMO, Raghunath Ayurved Mahavidyalaya and Hospital, Contai, W.B., India

${ }^{3}$ Assistant Professor Dept. of Shalya Tantra, Raghunath Ayurved Mahavidyalaya and Hospital, Contai, W.B., India

${ }^{4}$ Associate Professor Depart of Kayachikitsa, Raghunath Ayurved Mahavidyalaya and Hospital, Contai, W.B., India

Corresponding Author: dr.dipanjanjana@gmail.com

\section{https://doi.org/10.46607/iamj3109092021}

(Published Online: September 2021)

Open Access

(C) International Ayurvedic Medical Journal, India 2021

Article Received: 20/08//2021 - Peer Reviewed: 02/09/2021 - Accepted for Publication: 03/09/2021

\section{Check for updates}

\section{ABSTRACT}

Panchakarma is a fundamental part of Ayurveda. It is chiefly constituted of especially deliberate five procedures for detoxification of the body. These include Vamana (emesis therapy), Virechana (purgation therapy), Basti (therapeutic enema), Nasya (errhine therapy) and Raktamokshana (bloodletting therapy). Acharya Sushruta father of surgery mainly deals with Chaladanta in Sushruta Samhita. Shalya Tantra. It is carried out with the help of different surgical apparatuses like Yantra, Shastra and Anushastra. Panchakarma is not only a sohana (biopurificatory) process but involves a wide range of therapeutics such as samana(therapeutic) brahmana (rejuvenating), Ropana (healing), lekhana (scraping), prasamak (soothing). Acharya susruta explained widely Vranasastiupakram as with applications in the practice of Shalya Tantra i.e, Ayurvedic discipline of surgery. Numerous textual references are available where the procedures of Panchakarma and up karmas have been adopted as an important measure to Vrana Ropana along with the institution of surgical mediation directly or partially. 
Keywords: Panchakarma, Vrana, Vrana Swastiuakram, Shalya Tantra, Rakta-Mokshana.

\section{INTRODUCTION}

In Ayurveda science, Panchakarma has a very effective role in detoxifying and antioxidants to the body, mind and soul. It includes five major procedures i.e. Vamana (Emesis), Virechana (Purgation), Basti (Enema), Nasya (Instillation) and Rakta-mokshana (Bloodletting), and some associate procedures (upakarmas) like snehana, swedana, abhyanga, porishake, upanaha, kabal etc. Which plays a vital role in the preservation and maintenance of health \& promotion of longevity and also terminates the diseases ${ }^{[1]}$. In the context of Astanga Ayurveda Panchakarma not maintained but it persists in eight branches of treatment modality. Various Panchakar$m a$ therapies have an effective role on various diseases of surgical background in Ayurvedic treatment tools like asvrana, Ashmari, Slipada, Pleehodara, Bhagna, Arshas, Bhagandara, GudaBhramsa etc. in the context Acharya susruta explained vrana repeatedly, probably any types of wounds before or after surgery, maybe collated with vrana, either it is sadyavarana (acute) or dustavrana (chronic). Vranaswastiupakramas are the pathway to denotes the curative and preventive aspects of vrana. In Panchakarma background, it acts not only the purificato- ry purposes but is also used as surgical and presurgical interventions in various surgical diseases. Vranaswastiupakramas contains various panchakarma procedures for the treatment of vrana.

\section{AIM AND OBJECTIVE:}

1. To evaluate, elaborate and discuss the various Panchakarma measures mentioned in the Shashti-upakrama of Sushruta Samhita.

2. To understand the basic principle of wound management by Panchakarma measures.

VRANA: Vrana explained by Acharya Sushruta, means the discolouration of the body tissues. ${ }^{[2]}$ It is of two types i.e. Sharira / NijaVrana (intrinsic wounds, occurs due to the vitiation of dosha) and Agantujavrana (exogenous wounds, caused by trauma). ${ }^{[3]}$ VranaChikitsa (wound healing measures) is the most important part of the practice of ShalyaTantra. Various Panchakarma procedures have effective roles in the Vranachikitsa.

VRANA SHASTI UPAKRAMA: Acharya Sushruta explained sixty types of Upakramas (treatment tools) for the management of the various types of Vrana (wound/ulcer). They are as follows in the below $-{ }^{[4]}$

\begin{tabular}{|l|l|l|l|l|}
\hline \multicolumn{6}{|l|}{ Name of the ShastiUpakramas by Acharya Sushruta } & \\
\hline 1) Apatarpana & 13) Chedana & 25) Nirvapana & 37) Mridu Karma & 49) Patradana \\
\hline 2) Alepa & 14) Bhedana & 26) Utkarika & 38) Daruna Karma & 50) Krimighna \\
\hline 3) Parisheka & 15) Darana & 27) Kashaya & 39) Kshara Karma & 51) Brimhana \\
\hline 4) Abhyanga & 16) Lekhana & 28) Varti & 40) Agni Karma & 52) Vishaghna \\
\hline 5) Swedan & 17) Eshana & 29) Kalka & 41) Krishna Karma & 53) Shiro-virechana \\
\hline 6) Vimlapana & 18) Aharana & 30) Sarpi & 42) Pandu Karma & 54) Nasya \\
\hline 7) Upanaha & 19) Vyadhana & 31) Taila & 43) Pratisarana & 55) Kavaladharana \\
\hline 8) Pachana & 20) Vidravana & 32) Rasakriya & 44) Romasanjanana & 56) Dhuma \\
\hline 9) Visrabana & 21) Sivana & 33) Avachurnana & 45) Lomapaharana & 57) Madhu-Sarpi \\
\hline 10) Snehana & 22) Sandhana & 34) Vranadhupana & 46) Vasti & 58) Yantra \\
\hline 11) Vamana & 23) Pidana & 35) Utsadana & 47) UttaraVasti & 59) Ahara \\
\hline 12) Virechana & 24)Shonita- & 36) Avasadana & 48) Bandha & 60)Raksha-vidhana \\
\hline & sthapana & & & \\
\hline
\end{tabular}




\section{DISCUSSION}

Alepa: Alepa is the $2^{\text {nd }}$ no. of ShastiUpakarma. The medicines that are in the form of a paste and used for external application are called lepas. Acharya Sushruta described three types of Lepa, are - Pralepa, Pradeha, Alepa. Alepa will be moderate and is useful in Rakta and Pittadosa Pradhana skin diseases. ${ }^{[5]}$ It acts as VranaPrahyadana, VranaSodhana, Sophahara, Utsadana and Ropana. ${ }^{[6]}$

Parisheka: Parisheka is the $3^{\text {rd }}$ ShastiUpakrama, the process in which pouring of liquids e.g. Kwatha, Taila, Ghrita, Dugdha, Kanji etc. over the body from a specific height. In the condition of VatajaSopha along with pain, there Parisheka with heated Ghrita, Taila, Kanji, Mansa rasa are given. In Pittaja, Raktaja and Avighataja, VishajaSopha, Parisheka with Cold type of Dugdha (milk), Ghrita, Madhu, Sharkara-udaka (Sweet water), Ikshu rasa (sugarcane juice), Kshiri-vrikshaKwatha. In KaphajaSopha, Parisheka with heated Taila, Mutra, Kshara-udaka, Sura advised. $^{[7]}$

Avyanga: Avyanga is the $4^{\text {th }}$ ShastiUpakrama, is mainly comes under BahyaSnehana, in which anointing the body parts with oil, ghee etc. with direction to the hair. Depends on the condition of Dosha and Mala, Avyanga acts on Vrana, diminishes the aggravation of the doshas and produces softness in the body. ${ }^{[8]}$

Swedana: Swedana is the $5^{\text {th }}$ ShastiUpakrama, which is termed as the procedure by which the sweat or perspiration is produced from the body (Swedakara). It relieves Stambha (stiffness), Gaurava (heaviness), Sitaghna (coldness). ${ }^{\left[{ }^{9]}\right.}$ Acharya Sushruta mentioned in VranaShastiupakrama, Swedana cures swelling, which is painful, big (Daruna), hard (Kathina). ${ }^{[10]}$

Upanaha: Upanaha is the $7^{\text {th }}$ ShastiUpakrama, which is done by bandhana (bandaging), applied with the medicated paste over the Vrana or affected body parts. ${ }^{[11]}$ Its effects on Avidagdhavrana turn to its mitigation and also VidagdhaVrana turn to its maturation. ${ }^{[12]}$

Visrabana: Visrabana is the $9^{\text {th }}$ ShastiUpakrama, is a procedure in which removing the vitiated blood is a diseased condition, occur due to vitiation of Rakta and Pitta dosha. This measure is performed by using Shastra (sharp surgical instruments) e.g. Siravyadhana, Pracchana and Anu-shastra (Para-surgical measures) e.g. Jalauka. In the recent onset of swelling, Raktamokshana karma is highly effective in reducing pain and helps to Pakwaavastha (suppurated state). In Achira-utpattiSopha (acute swelling) which are Kathina (hard), dark-red discolouration with pain, raktamokshana is suitable for that condition. In the condition of Swelling due to poison, Jalaukaavacharana is the preferable condition for that. ${ }^{[13]}$

Snehana: 'Snehana' means 'Oleation therapy' that may be processed externally or internally along with various snehadravyas, produces Snigdhata (oiliness), Visyandana (liquefaction), Mardava (softness), and Kleda karaka (moistness) in the body. ${ }^{[14]}$ In the conditions of a dry \& emaciated person having swollen and occurring complications, snehapana is advised. It reduces pain and helps in the early process of suppuration. ${ }^{[15]}$

Sarpi: Sarpi is the $30^{\text {th }}$ ShastiUpakrama. It is one and best among the ChaturaSneha, because of its unique property "SamskarasyaAnuvartanaat". ${ }^{[16]}$ It is used for external or internal oleation purposes. In case of the swelling, which is a pitta aggravated state, deeprooted with burning sensation, sarpi is beneficial. ${ }^{[17]}$

Taila: Taila is the $31^{\text {th }}$ ShastiUpakrama. It is the best Vatahara in mahasneha and improves strength, is beneficial for skin, strengthens the muscles, helps in Yoni Vishodhana. ${ }^{[18]}$ In the case of elevated muscles which are dry, having fewer exudates, mustard oil is applied. ${ }^{[19]}$

Vamana: Vamana is the $11^{\text {th }}$ ShastiUpakrama. Vama$n a$ is the procedure by which expels the vitiated kaphadoshas through the upward direction of the body (Urdhwabhaga) i.e. mouth by using suitable medications. ${ }^{[20]}$ It is indicated in the swelling occurs due to elevation of muscles (mansa), having aggravated kaphadosha and blood clotted slightly black swelling (Rudhiravarnasopha). ${ }^{[21]}$

Virechana: Virechana is the procedure by which expels the vitiated doshas through the downward direction of the body (Adhobhaga) i.e. anus by using suitable medications. ${ }^{[22]}$ In the Chronic stage of swelling 
and vata-pittajaVrana, Virechana karma should be performed. ${ }^{[23]}$ It is the $12^{\text {th }}$ ShastiUpakrama.

Utsadana: Utsadana means massaging of opposite directions to the hair follicles (body) with drugs mixed with Sneha or oil or other liquids in the form of Kalka. ${ }^{[24]}$ In the dry type of swelling (Parishuska), having less no of muscles (alpamansa) and deeprooted (gambhira) swelling, Lepa prepared by medicated drugs with ghrita should be used. ${ }^{[25]}$ It is the $35^{\text {th }}$ ShastiUpakrama.

Basti: Basti is the $46^{\text {th }}$ ShastiUpakrama. Acharya Charaka told that Vastichikitsa is the ArdhwaChikitsa ${ }^{[26]}$, in this process the medicinal measures are administered through the Ano-rectally. It is also considered as the prime treatment of all Panchakarma measures, because of its main pacifying measures of Vatadosha. ${ }^{[27]}$ The swellings which are dry with severe pain vitiated due to vatadosha and are situated in the lower part of the body, Basti is indicated in such cases. ${ }^{[28]}$

UttaraBasti: UttaraBasti is the $47^{\text {th }}$ no. of ShastiUpakarma. It is classified into -

- Based on the route of administration: ${ }^{[29]}$

1) MutrashayagataUttaraVasti

2) GarbhashayagataUttaraVasti

It is especially beneficial on Vrana occurring due to Mutraghata, Mutradosha, Shukradosha, Ashmari and Artavadosha. ${ }^{[30]}$

Shiro-virechana: Shiro-virechana is the 53rd no. of ShastiUpakarma. In this process, Medicine or medicinal Sneha is applied through nostrils to mitigate the kaphadosha from Urdhwa-jatru (above clavicle), which is termed as Nasya. Acharya Susruta mainly classified the nasya into two i.e. Shiro-virechana and Snehana. Then further classified the nasya into five i.e. Nasya, Shiro-virechana, Pratimarsha, Avapida, Pradhamana. ${ }^{[31]}$ The swellings with itching sensation which are situated at supra-clavicular region (Urdhwa-jatru), advised to Shiro-virechana for the management. ${ }^{[32]}$

Nasya: Nasya is the $54^{\text {th }}$ no. of ShastiUpakarma. It is a procedure by which administering the medicine or medicated sneha through the nose. ${ }^{[33]}$ Swelling with pain due to vitiated Vatadosha, situated above the shoulder, Nasya is performed. ${ }^{[34]}$

KavalaDharana: KavalaDharana is the $55^{\text {th }}$ no. of ShastiUpakarma. It is the procedure of holding the hot or cooled medicated sneha in the mouth with a suitable capacity which is moves inside. ${ }^{[35]}$ It mitigates the vitiated doshas, reduces the pain, burning sensation from the oral cavity, removes the malas (vitiated doshas) of the tongue, teeth \& oral cavity. ${ }^{[36]}$ Dhumapana: Dhumapana is the $56^{\text {th }}$ no. of ShastiUpakarma. It is a type of Nasya, where medicated smoke is inhaled through nostrils and mouth, exhalation through the only mouth. ${ }^{[37]}$ Acharya Sushruta mentioned it for treated the Urdhwajatrugatavrana which occur due to vitiation of VataandKaphadosha associated with swelling, exudation and pain. ${ }^{[38]}$

\section{CONCLUSION}

Panchakarma is a unique therapy that can be maintenance and conservation of health, along with the promotion of longevity with a healthy individual. In the field of ShalyaTantra, the procedures of Panchakarma combined to effect on vranoropana. Shalyatantra is not only surgical ore pre-surgical management, of numerous surgical conditions requires adjuvant therapies of Panchakarma. By adopting these procedures, the practice of ShalyaTantra is sure to be benefitted from improved outcomes. Panchakarma and eight branches of Ayurveda combined package of Ayurveda.

\section{REFERENCES}

1. Dr Brahmananda Tripathi, Astanga Hridayam of SrimadVagbhata, Nirmala Hindi Commentary, Sutra Sthana, Chapter 14, Verse 05, Ed. Reprint, Chaukhambha Sanskrit Pratishthan, Delhi, 2015, P.191192.

2. Kaviraj Ambika Dutta Shastri, Susruta Samhita of MaharsiSusruta, Ayurveda Tattva Sandipika Hindi Commentary, Vol. I, Chikitsa Sthana, Chapter 01, Verse 06, Ed. Reprint, Chaukhambha Sanskrit Sansthan, Varanasi, 2016, P.04.

3. Kaviraj Ambika Dutta Shastri, Susruta Samhita of Maharsi Susruta, Ayurveda TattvaSandipika Hindi Commentary, Vol. I, ChikitsaSthana, Chapter 01, 
Verse 03, Ed. Reprint, Chaukhambha Sanskrit Sansthan, Varanasi, 2016, P.01.

4. Kaviraj Ambika Dutta Shastri, Susruta Samhita of MaharsiSusruta, Ayurveda TattvaSandipika Hindi Commentary, Vol. I, ChikitsaSthana, Chapter 01, Verse 08, Ed. Reprint, Chaukhambha Sanskrit Sansthan, Varanasi, 2016, P.05.

5. Kaviraj Ambika Dutta Shastri, Susruta Samhita of MaharsiSusruta, Ayurveda TattvaSandipika Hindi Commentary, Vol. I, Sutra Sthana, Chapter 18, Verse 06-07, Ed. Reprint, Chaukhambha Sanskrit Sansthan, Varanasi, 2016, P.97.

6. Kaviraj Ambika Dutta Shastri, Susruta Samhita of MaharsiSusruta, Ayurveda Tattva Sandipika Hindi Commentary, Vol. I, Chikitsa Sthana, Chapter 01, Verse 16, Ed. Reprint, Chaukhambha Sanskrit Sansthan, Varanasi, 2016, P.06.

7. Kaviraj Ambika Dutta Shastri, Susruta Samhita of MaharsiSusruta, Ayurveda Tattva Sandipika Hindi Commentary, Vol. I, Chikitsa Sthana, Chapter 01, Verse 17, Ed. Reprint, Chaukhambha Sanskrit Sansthan, Varanasi, 2016, P.06.

8. Kaviraj Ambika Dutta Shastri, Susruta Samhita of MaharsiSusruta, Ayurveda TattvaSandipika Hindi Commentary, Vol. I, ChikitsaSthana, Chapter 01, Verse 19, Ed. Reprint, Chaukhambha Sanskrit Sansthan, Varanasi, 2016, P.07.

9. Vd. Harish Chandra Singh Kushwaha, Charaka Samhita, Ayurveda Dipika's Ayushi Hindi Commentary, Vol. I, Sutra Sthana, Chapter 22, Verse 11, 1st Ed. Chaukhambha Orientalia, Varanasi, 2009, P.320.

10. Kaviraj Ambika Dutta Shastri, Susruta Samhita of Maharsi Susruta, Ayurveda TattvaSandipika Hindi Commentary, Vol. I, Chikitsa Sthana, Chapter 01, Verse 21, Ed. Reprint, Chaukhambha Sanskrit Sansthan, Varanasi, 2016, P.07.

11. Kaviraj Ambika Dutta Shastri, Susruta Samhita of Maharsi Susruta, Ayurveda Tattva Sandipika Hindi Commentary, Vol. I, Chikitsa Sthana, Chapter 32, Verse 12, Ed. Reprint, Chaukhambha Sanskrit Sansthan, Varanasi, 2016, P.174.

12. KavirajAmbika Dutta Shastri, SusrutaSamhita of MaharsiSusruta, Ayurveda TattvaSandipika Hindi Commentary, Vol. I, ChikitsaSthana, Chapter 01, Verse 23-24, Ed. Reprint, Chaukhambha Sanskrit Sansthan, Varanasi, 2016, P.07.

13. KavirajAmbika Dutta Shastri, SusrutaSamhita of MaharsiSusruta, Ayurveda TattvaSandipika Hindi Commentary, Vol. I, ChikitsaSthana, Chapter 01, Verse
27-29, Ed. Reprint, Chaukhambha Sanskrit Sansthan, Varanasi, 2016, P.08.

14. Vd. Harish Chandra Singh Kushwaha, Charaka Samhita, Ayurveda Dipika'sAyushi Hindi Commentary, Vol. I, Sutra Sthana, Chapter 22, Verse 11, 1st Ed. ChaukhambhaOrientalia, Varanasi, 2009, P.320.

15. KavirajAmbika Dutta Shastri, SusrutaSamhita of MaharsiSusruta, Ayurveda TattvaSandipika Hindi Commentary, Vol. I, ChikitsaSthana, Chapter 01, Verse 30-31, Ed. Reprint, Chaukhambha Sanskrit Sansthan, Varanasi, 2016, P.08.

16. Dr BrahmanandaTripathi, AstangaHridayam of SrimadVagbhata, Nirmala Hindi Commentary, Sutra Sthana, Chapter 16, Verse 02, Ed. Reprint, Chaukhambha Sanskrit Pratishthan, Delhi, 2015, P.204.

17. KavirajAmbika Dutta Shastri, SusrutaSamhita of MaharsiSusruta, Ayurveda TattvaSandipika Hindi Commentary, Vol. I, ChikitsaSthana, Chapter 01, Verse 56, Ed. Reprint, Chaukhambha Sanskrit Sansthan, Varanasi, 2016, P.10.

18. Vd. Harish Chandra Singh Kushwaha, Charaka Samhita, Ayurveda Dipika'sAyushi Hindi Commentary, Vol. I, Sutra Sthana, Chapter 13, Verse 15, 1st Ed. ChaukhambhaOrientalia, Varanasi, 2009, P.201.

19. KavirajAmbika Dutta Shastri, SusrutaSamhita of MaharsiSusruta, Ayurveda TattvaSandipika Hindi Commentary, Vol. I, ChikitsaSthana, Chapter 01, Verse 57-58, Ed. Reprint, Chaukhambha Sanskrit Sansthan, Varanasi, 2016, P.10.

20. Vd. Harish Chandra Singh Kushwaha, Charaka Samhita, Ayurveda Dipika'sAyushi Hindi Commentary, Vol. II, KalpaSthana, Chapter 01, Verse 04, 1st Ed. ChaukhambhaOrientalia, Varanasi, 2009, P.852.

21. KavirajAmbika Dutta Shastri, SusrutaSamhita of MaharsiSusruta, Ayurveda TattvaSandipika Hindi Commentary, Vol. I, ChikitsaSthana, Chapter 01, Verse 31-32, Ed. Reprint, Chaukhambha Sanskrit Sansthan, Varanasi, 2016, P.08.

22. Vd. Harish Chandra Singh Kushwaha, Charaka Samhita, Ayurveda Dipika'sAyushi Hindi Commentary, Vol. II, KalpaSthana, Chapter 01, Verse 04, 1st Ed. ChaukhambhaOrientalia, Varanasi, 2009, P.852.

23. KavirajAmbika Dutta Shastri, SusrutaSamhita of MaharsiSusruta, Ayurveda TattvaSandipika Hindi Commentary, Vol. I, ChikitsaSthana, Chapter 01, Verse 32-33, Ed. Reprint, Chaukhambha Sanskrit Sansthan, Varanasi, 2016, P.08.

24. KavirajAmbika Dutta Shastri, SusrutaSamhita of MaharsiSusruta, Ayurveda TattvaSandipika Hindi Com- 
mentary, Vol. I, Dalhana's Commentary on ChikitsaSthana, Chapter 24, Verse 53, Ed. Reprint, Chaukhambha Sanskrit Sansthan, Varanasi, 2016, P.135.

25. KavirajAmbika Dutta Shastri, SusrutaSamhita of MaharsiSusruta, Ayurveda TattvaSandipika Hindi Commentary, Vol. I, ChikitsaSthana, Chapter 01, Verse 81-82, Ed. Reprint, Chaukhambha Sanskrit Sansthan, Varanasi, 2016, P.12.

26. Vd. Harish Chandra Singh Kushwaha, Charaka Samhita, Ayurveda Dipika'sAyushi Hindi Commentary, Vol. II, Siddhi Sthana, Chapter 01, Verse 38-40, 1st Ed. ChaukhambhaOrientalia, Varanasi, 2009, P.953.

27. Prof. Jyotir Mitra, Astanga Samgraha of Srimada Vriddha Vagbhata, Indu's Shashilekha Sankrit Commentary, Sutra Sthana, Chapter 28, Verse 02, $4^{\text {th }}$ Ed, Chowkhamba Sanskrit Series Office, Varanasi, 2016, P. 212.

28. Kaviraj Ambika Dutta Shastri, Susruta Samhita of MaharsiSusruta, Ayurveda TattvaSandipika Hindi Commentary, Vol. I, ChikitsaSthana, Chapter 01, Verse 109, Ed. Reprint, Chaukhambha Sanskrit Sansthan, Varanasi, 2016, P.15.

29. Dr Brahmananda Tripathi, AstangaHridayam of Srimad Vagbhata, Nirmala Hindi Commentary, Sutra Sthana, Chapter 19, Verse 70, Ed. Reprint, Chaukhambha Sanskrit Pratishthan, Delhi, 2015, P.240.

30. KavirajAmbika Dutta Shastri, Susruta Samhita of MaharsiSusruta, Ayurveda Tattva Sandipika Hindi Commentary, Vol. I, ChikitsaSthana, Chapter 01, Verse 110, Ed. Reprint, Chaukhambha Sanskrit Sansthan, Varanasi, 2016, P.15.

31. Kaviraj Ambika Dutta Shastri, Susruta Samhita of MaharsiSusruta, Ayurveda TattvaSandipika Hindi Commentary, Vol. I, ChikitsaSthana, Chapter 40, Verse 21, Ed. Reprint, Chaukhambha Sanskrit Sansthan, Varanasi, 2016, P.224.

32. KavirajAmbika Dutta Shastri, SusrutaSamhita of MaharsiSusruta, Ayurveda TattvaSandipika Hindi Commentary, Vol. I, ChikitsaSthana, Chapter 01, Verse 125, Ed. Reprint, Chaukhambha Sanskrit Sansthan, Varanasi, 2016, P.16.

33. KavirajAmbika Dutta Shastri, SusrutaSamhita of MaharsiSusruta, Ayurveda TattvaSandipika Hindi Commentary, Vol. I, ChikitsaSthana, Chapter 40, Verse 21, Ed. Reprint, Chaukhambha Sanskrit Sansthan, Varanasi, 2016, P.224.

34. KavirajAmbika Dutta Shastri, SusrutaSamhita of MaharsiSusruta, Ayurveda TattvaSandipika Hindi Com- mentary, Vol. I, ChikitsaSthana, Chapter 01, Verse 126, Ed. Reprint, Chaukhambha Sanskrit Sansthan, Varanasi, 2016, P.16.

35. KavirajAmbika Dutta Shastri, SusrutaSamhita of MaharsiSusruta, Ayurveda TattvaSandipika Hindi Commentary, Vol. I, ChikitsaSthana, Chapter 40, Verse 62, Ed. Reprint, Chaukhambha Sanskrit Sansthan, Varanasi, 2016, P.229.

36. KavirajAmbika Dutta Shastri, SusrutaSamhita of MaharsiSusruta, Ayurveda TattvaSandipika Hindi Commentary, Vol. I, ChikitsaSthana, Chapter 01, Verse 127-128, Ed. Reprint, Chaukhambha Sanskrit Sansthan, Varanasi, 2016, P.16.

37. KavirajAmbika Dutta Shastri, SusrutaSamhita of MaharsiSusruta, Ayurveda TattvaSandipika Hindi Commentary, Vol. I, ChikitsaSthana, Chapter 40, Verse 07, Ed. Reprint, Chaukhambha Sanskrit Sansthan, Varanasi, 2016, P.222.

38. KavirajAmbika Dutta Shastri, SusrutaSamhita of MaharsiSusruta, Ayurveda TattvaSandipika Hindi Commentary, Vol. I, ChikitsaSthana, Chapter 01, Verse 129, Ed. Reprint, Chaukhambha Sanskrit Sansthan, Varanasi, 2016, P.16.

\section{Source of Support: Nil \\ Conflict of Interest: None Declared}

How to cite this URL: Dipanjan Jana et al: A Review On Clinical Importance Of Panchakarma In Vrana Shasti Upakramas. International Ayurvedic Medical Journal \{online\} 2021 \{cited September 2021\} Available from: http://www.iamj.in/posts/images/upload/2129_2134.pdf 